\title{
Retraction
}

\section{Retracted: How to Perfuse: Concepts of Cerebral Protection during Arch Replacement}

\author{
BioMed Research International \\ Received 24 March 2016; Accepted 24 March 2016 \\ Copyright (C) 2016 BioMed Research International. This is an open access article distributed under the Creative Commons \\ Attribution License, which permits unrestricted use, distribution, and reproduction in any medium, provided the original work is \\ properly cited.
}

The article titled "How to Perfuse: Concepts of Cerebral Protection during Arch Replacement" [1] has been retracted as it was found to contain passages of text copied from the following published article: "Modern temperature management in aortic arch surgery: the dilemma of moderate hypothermia," by Maximilian Luehra, Jean Bachetb, Friedrich-Wilhelm Mohra, and Christian D. Etza, in The European Journal of Cardio-Thoracic Surgery, vol.45, no. 1, pp.27-39, 2014. Dr. Andreas Habertheuer has assumed all responsibility for the copied text in the article.

\section{References}

[1] A. Habertheuer, D. Wiedemann, A. Kocher, G. Laufer, and P. Vallabhajosyula, "How to perfuse: concepts of cerebral protection during arch replacement," BioMed Research International, vol. 2015, Article ID 981813, 10 pages, 2015. 